İş ve İnsan Dergisi I The Journal of Human and Work

Y1l | Year: Nisan | April 2021

Cilt-Sayı | Volume-Issue: 8 (1)

ss | pp: $59-72$

doi: 10.18394/iid.807278

e-ISSN 2148-967X

http://dergipark.gov.tr/iid/

Araştırma Makalesi

\title{
Kariyer Dönemlerinin Değişmeyen Gerçeği: Kariyer Endişesi
}

\author{
The Unchanging Truth of Career Stages: Career Anxiety
}

\author{
Hazel Aguna ${ }^{a}$ Dilek Işılay Üçok ${ }^{b}$, Burcu Aydın Küçük ${ }^{c}$
}

MAKALE BİLGİSI

Anahtar Kelimeler:

Kariyer Endişesi,

Kariyer Dönemleri,

Kariyer Yönetimi,

Insan Kaynaklarl Yönetimi

Nitel Araştırma Yöntemi.

Tarihler :

Geliş 8 Ekim 2020

Kabul 26 Ocak 202

\section{A R T I C L E I N F O}

\section{Keywords:}

Career Anxiety,

Career Stages,

Career Management, Human

Resources Management,

Qualitative Method.

Article history:

Received 8 October 2020

Accepted 26 January 2021

\begin{abstract}
ÖZ
Kariyer endişesi; kişinin çalı̧̧ma hayatında kariyeriyle ilgili kendisini tehdit eden ve/veya belirsizlik yaşamasına neden olan bir durumla karşı karșıya kaldığında ortaya çıkan duygu durumu olarak tanımlanmaktadır. Bu çalışmada; kurumlarda çalışan kişilerin yaşamış olduklar kariyer endișesinin altında yatan konuları tespit etmek amacıyla nitel araștırma yöntemi tercih edilmiş ve hem kamu sektöründe hem de özel sektördeki farklı örgütlerde çalışan 37 katılımcıyla derinlemesine mülakatlar gerçekleştirilmiştir. Yapılan görüşmeler sonucunda söz konusu endişenin arka planında bireysel, örgütsel, teknolojik ve toplumsal konular başta olmak üzere çalıșma arkadașları, yönetici ve istihdam ile ilgili konulardan kaynaklandığl ortaya konulmuş ve çalışanların bu endişeyle baş edebilme yolları sıralanmıştır. Bu çallş̧manın, kariyerini yerleştirme/sürdürme döneminde olan çalışanların yaşamış oldukları kariyer endişesinin altında yatan nedenleri belirlemeye yönelik olarak yapılan bir nitel çalışma olması nedeniyle alanyazına katkıda bulunacağına ve konuyla ilgili gelecekte yapılacak araştırmalara zemin oluşturacă̆ına inanılmaktadır.
\end{abstract}

\begin{abstract}
A B S T R A C T
Career anxiety is defined as the state of emotion which occurs when people are faced with a situation that threatens them and / or causes an uncertainty about their career in business life. In this study, qualitative research method is preferred and in-depth interviews are performed with 37 participants who work in different organizations both in the public and private sector to identify the underlying factors of career anxiety. The interviews reveal that career anxiety is derived from collegues, managers, employment issues, particulary those related to individual, organizational, technological, social issues and the implications are listed for employees to deal with this anxiety. It is also believed that this study will contribute to the national literature as it is the study that has been conducted with a qualitative method on career anxiety which is experienced by the employees who are in the stage of establishing/maintaining their career and will form the basis for future research on this topic.
\end{abstract}

\footnotetext{
a İletişim kurulacak yazar, Dr., Marmara Üniversitesi, İktisat Fakültesi, Çalışma Ekonomisi ve Endüstri İlişkileri Bölümü, İstanbul, Türkiye, hazel.agun@marmara.edu.tr,ORCID: 0000-0003-3211-8794

${ }^{\mathrm{b}}$ Dr. Öğr. Üyesi., Doğuş Üniversitesi, İktisadi ve İdari Bilimler Fakültesi, İşletme (İngilizce) Bölümü, Istanbul, Türkiye, disilay@dogus.edu.tr, ORCID: 0000-0002-6849-0531

${ }^{\mathrm{c}} \mathrm{Dr}$. Öğr. Üyesi., İstanbul Aydın Üniversitesi, İktisadi ve İdari Bilimler Fakültesi, Havacılık Yönetimi Bölümü, İstanbul, Türkiye, burcukucuk@aydin.edu.tr ORCID: 0000-0001-9081-2536
} 


\section{GİRIŞ}

Günümüz dünyasında küreselleşme ile birlikte teknoloji, ekonomi ve çalışma hayatının yarattığı köklü ve hızlı gelişmeler kişilerin yaşamını etkilemektir. $\mathrm{Bu}$ değişim sürecine çalışanlar açısından bakıldığında ise etkilenen temel yaşam alanının kariyer olduğu bilinmektedir (Fiori, Bollmann \& Rossier, 2015). Kariyer; bireylerin işteki deneyimleriyle bağlantılı olarak yaşamları boyunca elde ettikleri kişisel kazanım ve tecrübeler bütünü olarak ifade edilmektedir (Köktürk, 2000; Super, 1990). Ancak, çalışma hayatında önemli rolü olan mikro ve makro düzeyde değişimler (ör. istihdam politikalarının değişmesi, işgücü piyasasındaki belirsizlikler, iş güvencesizliğindeki artış ve örgütlerdeki küçülme kararları) söz konusu geleneksel kariyer kavramının da içeriğini değiştirmiştir (Savickas vd., 2009). Kariyer algısında yaşanan bu değişim aynı zamanda çalışanların kariyerleri boyunca karşılaştıkları belirsizlikleri de çok yönlü bir hale getirmiştir (Fiori vd., 2015). Çalışma ortamında görülen bu belirsizliklerin artan iş yükünden ve sorumluluklardan dolayı çalışanlarda strese yol açtığı alanyazından edinilen bilgiler arasındadır (Aytaç, 2009). Örgütlerde ortaya çıkan stres kaynaklarının, kişilerin duygu, tutum ve davranışlarını etkileyerek bilişsel, psikolojik ve fizyolojik yapılarını baskı altına aldığı görülmektedir (Gordon, 1994). Bu nedenle çalışma ortamında karşılaşılan stres kaynaklarının çalışanlarda kariyerleriyle ilgili endişe, kaygı ve korku benzeri duygulara zemin hazırlaması beklenilen bir durumdur (Altan, 2018).

Kariyer endişesi, kişinin çalışma yaşamında kariyeriyle ilgili belirsizlik ve/veya kendisini tehdit eden bir unsurla karşılaşması sonucu ortaya çıkan durum olarak açıklanmaktır (Pisarik, Rowell \& Thompson, 2017). Kişilerin kariyerleriyle ilgili olumlu/olumsuz algıların oluşmaya başladığı zamanın iş hayatına ilk başladıkları dönemler olduğu, özellikle yirmili yaşlardaki kişilerin bu dönemde yoğun bir endişe duydukları ifade edilmektedir (Pisarik vd., 2017; Savickas, 2001). $\mathrm{Bu}$ dönemde; çalışma ortamından, çevredeki uyarıcılardan ve bireysel özelliklerden kaynaklanan stres faktörlerinin de çalışanların endişelerini tetiklediği düşünüldüğünde, bu endişenin sadece yaşa ya da kariyerin ilk keşfedildiği döneme özgü bir duygudan ziyade, kariyer yolculuğunun bütününde dikkate alınması gereken çok yönlü bir olgu olduğu dikkati çekmektedir (Savickas, 2001; Şahin, Özaydın \& Siyez, 2019). Öyle ki, çalışma hayatının içerisinde olan bireyler işte öğrenmeye devam etmektedir ve mesleklerinde ilerledikçe kariyeri sürdürme döneminde bir üst basamağ hedeflemektedir. $\mathrm{Bu}$ durum McClelland'ın Öğrenilmiş İhtiyaçlar Kuramı ve Alderfer'in Varoluş-İlişki Kurma ve Gelişme Gereksinimleri Kuramında açıklanmıştır. David McClelland (1961), "The Achieving Society" adlı eserinde insanoğlunun üç temel motivasyon aracına ihtiyaç duyduğundan bahseder: ilişki ihtiyacı, başarma ihtiyacı ve güç ihtiyacı. Sosyo-demografik özellikler gözetmeksizin kuramın evrenselliğine dikkat çeken McClelland insanoğlunda bu üç ihtiyaçtan birinin baskın olduğunu ve kültüre ve bireysel tecrübelere dayanarak bireyin hayatına yön verdiğini ifade etmektedir. Benzer şekilde Alderfer (1972) ise kuramında insanoğlunun varoluş, ilişki kurma ve gelişme gereksinimlerini vurgular. Hem Alderfer' in gelişme ihtiyacı hem de McClelland'ın başarı ihtiyacı yine Maslow'un (1943) kuramında bahsettiği kendini gerçekleştirme gereksinimi ile örtüşmektedir. Bu basamaklar başarı ve sorumluluk ihtiyaçlarını içererek bireyin saygınlık gereksinimine dikkat çekmektedir (Johns \& Saks, 2001). Bu bilgiler 1şı̆̆ında, birey kariyerini sürdürme aşamasında her ne kadar çalışma ihtiyacını karşılamış ve hayatını sürdürebilecek maddi kaynaklara erişmiş olsa da başarma ve güç ihtiyacını karşılamak için kariyer yolculuğunda bir üst basamağı (terfi) arzulayabilir. Kendini geliştiren bir çalışan başarılarının ödülü olarak bir üst basamağı hedeflerken üst basamaktaki resmi güç kaynakları bireyin kendini gerçekleştirme duygusunu tatmin etmeyebilir. Dolayısıla, birey kariyer dönemlerinde bu ihtiyaçlarını karşılayamadığı için kariyer endişesi yaşayabilmektedir.

İlgili alan yazın incelendiğinde, kariyer endişesiyle ilgili çalışmaların büyük çoğunluğunun üniversite öğrencileri ve kariyer gelişiminin başında olan yetişkin kişilerle (Hardin, Varghese, Tran \& Carlson. 2006; Pisarik vd., 2017; Şahin vd., 2019) yapıldığ1 tespit edilmiştir. Oysaki örgütsel (ör. rekabetin yönetimsel yansımaları), çevresel (ör. sürekli değişsen istihdam politikaları, sosyolojik ve ekonomik durumlar), teknolojik (ör. teknolojik gelişmelerdeki hız) ve bireysel (ör. çalışanlardaki iş güvencesizliği algısı ve bireysel motivasyon için gerekli olan psikolojik ihtiyaçlar gibi) nedenlerden dolayı kariyer yolculuğuna devam eden ve özellikle alanyazında belirtilen mesleki kariyer aralığından biri olan (Super, 1990) yerleşme (25- 44 yaş) ve sürdürme (45- 64 yaş) dönemindeki çalışan grubu üzerinde de benzer endişelerin olabileceği düşünülmektedir (Fiori vd., 2015). Bu nedenle, farklı kariyer dönemlerinde olan çalışanların yaşamış oldukları kariyer endişesinin ortaya konulmasının, bu endişeye neden olan faktörlerin tespit edilmesinin ve baş edebilme yöntemlerinin 
vurgulanmasının hem insan kaynakları yönetimi alanyazınına katkı sağlayacağı hem de konuyla ilgili bundan sonra yapılacak olan araştırmalara yol göstereceğine inanılmaktadır. $\mathrm{Bu}$ açıdan mevcut araştırmanın alanyazında söz konusu boşluğu doldurarak kariyer endişesi konusuna yeni bir bakış açısı kazandıracağı düşünülmektedir.

\section{KAVRAMSAL ÇERÇEVE}

Kariyer, bir kişinin yaşamı boyunca yaptığı meslek doğrultusunda kazandığı tecrübe, rol ve deneyimler bütünüdür (Wood, 2006). Herkesin yaşadığ 1 kariyer gelişiminin kendine özgü bir dönem olduğu ve bu gelişimin yaşam boyu devam eden bir süreç olarak ifade edildiği bilinmektedir (Super, 1990). Alanyazındaki kariyer gelişimi ile ilgili teoriler incelendiğinde, kariyer evrelerinin çeşitli çalıșmalarda farklı yaş aralıklarına göre ifade edildiği görülmektedir (Wang \& Wangberg, 2017). Geleneksel kariyer modellerindeki çalışmalarda, kariyer gelişimi aralıklı yaş dönemleri içerisinde belli bir doğrusallıkta devam etmektedir (Super, 1990; Brooks \& Seers, 1991). Günümüzde ise kariyer yönetimi ile ilgili çalı̧̧malarda geleneksel kariyer modelleri ile birlikte güncel kariyer modelleri de yer almaktadır. Güncel kariyer modelleri ise kariyer gelişimini keskin bir ayrımla ele almayıp esnek, değişken ve sınırsız kariyer modelleri ile kariyer yolunu açıklamaktadır (Sullivan \& Arthur, 2006; Wang \& Wangberg, 2017).

Super'in (1957) Kariyer Gelişimi Teorisinde kariyer gelişimi, kişinin yaş dönemlerine göre benzer bir şekilde basamaklara ayrılmaktadır (Wang \& Wangberg, 2017). Bunlar; büyüme dönemi (0-14 yaş), keşfetme dönemi (15-25 yaş), yerleşme dönemi (25-44 yaş), sürdürme dönemi (45-64 yaş) ve geri çekilme dönemi (65 yaş ve sonrası) olarak ele alınmaktadır. $\mathrm{Bu}$ dönemlerde kişiler, çeşitli etkenlerden dolayı kariyeriyle ilgili kararlar almakta, devam ettirmekte ya da kariyerlerini yönetmekte problem yaşamaktadırlar (Şahin vd., 2019). Kişilerin yaşamış oldukları problemlerin çok yönlü yapısı düşünüldüğünde, bu sürece endişe ve korku benzeri bir takım olumsuz duyguların da eşlik edeceğine inanılmaktadır. $\mathrm{Bu}$ bağlamda, kariyer endişesi, kişinin çalışma yaşamında kariyeriyle ilgili belirsizlik ve/veya kendisini tehdit eden bir unsurla karşılaşması sonucu ortaya çıkan bir duygu durumu olarak tanımlanmaktadır (Pisarik vd., 2017). Çalışma hayatında kişiler arasında yaşanan rekabetten dolay1 hissedilen psikolojik bask1 ve belirsizliğin, kişilerin psikolojik özelliklerinin (Schein, 1983), hızlı yaşanan örgütsel değişim süreçlerinin, mesleğe/sektöre has ekonomik ve teknolojik özelliklerin, çalışanların kariyerleriyle ilgili hissettikleri endişeleri arttırdığ 1 ifade edilmektedir (Aytaç \& Keser, 2002; Fiori vd., 2015).

Kariyer endişesi ile ilgili alanyazındaki çalışmalar incelendiğinde, bu durumun genellikle kariyerleriyle ilgili karar alma sürecindeki ergen kişilerde ya da mesleklerinin geleceği ile ilgili kararsızlık yaşayan/işe yeni başlayan yetişkinlerde ortaya çıkan bir durum olarak ele alındığ görülmektedir (Tsai, Hsu \& Yang, 2017; White \& Tracey, 2011). Konuyla ilgili yapılan bir diğer çalışmada (Saka, Gati \& Kelly, 2008) ise; kişilerin içinde bulundukları kariyer basamağından ya da meslek seçimindeki kararsızlıktan bağımsız olarak kariyerleriyle ilgili endișe yaşayabilecekleri ifade edilmektedir. Bir diğer ifadeyle, kișinin mesleki gelişimi, işe yerleşme ve sürdürme gibi kariyer aşamalarında da kariyer endişesinin ortaya çıkabileceği belirtilmektedir. Aynı zamanda, konuyla ilgili Super'in (1990) kendi teorisini revize ettiği kariyer gelişimi modeli ile bireyin kariyer evrelerinin yaşam süresi boyunca sabit olmayacağı ve birçok kariyer olaylarının bu döngüyü değiștirip etkileyeceği öne sürülmektedir (Şahin vd., 2019). $\mathrm{Bu}$ noktadan hareketle mevcut çalışmada, kariyer gelişim modellerinin bir konusu olan kariyer endişesi kavramı, konu üzerine yapılan çalıșmalar ışığında yeniden incelenmiştir.

Söz konusu araştırmalardan yola çıkılarak oluşturulan bu çalışmada; aşağıdaki araştırma soruları ile çalışma ortamında kişilerin yaşamış oldukları kariyer endişesinin altında yatan konuların ortaya konulmasina ve bu endişeyle baş etmeye yönelik yolların bulunmasına katkı sağlayacak yanitlar aranmaktadır.

1. Çalışma hayatında kişilerin yaşamış oldukları kariyer endișesi doğrultusunda bu endişenin altında yatan nedenler nelerdir?

2. Çalışanların yaşadıkları kariyer endişesiyle mücadele etmeleri için alınması gereken yollar nelerdir?

\section{YÖNTEM}

$\mathrm{Bu}$ çalışmada, çalışanların kariyerleri boyunca yaşamış oldukları endişe durumunun ve deneyimlerinin açı̆̆a çıarılabilmesi için nitel araştırma yöntemi kullanılmıştır (Miles \& Huberman, 1994). Aynı zamanda, çalıșanların kariyer endişesi yaşamalarına neden olabilecek faktörlerin açığa çıkarılabilmesi ve kariyer algılarına yönelik kapsamlı bir bakış açısına 
ulaşabilmek için nitel araştırma yöntemleri arasında yer alan olgubilim (fenomolojik) yaklaşımı benimsenmiştir. Olgubilim araştırmalarında amaç; kişilerin bir olguya dair yaşantılarını, algılarını ve bunlara yüklediği anlamları ortaya çıkarmaktır. $\mathrm{Bu}$ doğrultuda, çalışma grubunda yer alan kişilerin söz konusu olguyla ilgili öznel deneyimlerinin ifadelerinin belirli kavramlar ve temalar çerçevesinde tanımlanması mümkün olmaktadır. Veri toplama araci olarak, olgubilim araştırmalarında sıklıkla kullanılan görüşme tekniği benimsenmiş ve çalışma grubunda yer alan kişilerle derinlemesine mülakatlar gerçekleştirilmiştir. Veri analizi aşamasında ise, içerik analizi yöntemi tercih edilmiş ve görüşmeler sırasında elde edilen veriler, (1) verilerin kodlanmasi, (2) kod, kategori ve temaların bulunması, (3) kod, kategori ve temaların düzenlenmesi ile (4) bulguların tanımlanması ve yorumlanması olarak adlandırılan dört aşamada analiz edilmiştir (Miles \& Huberman, 1994).

\subsection{Araştırma Alanı ve Çalışma Grubu}

$\mathrm{Bu}$ araştırmada çalışma grubu olarak örnekleme yöntemlerinden erişilebilirlik ve gönüllülük esasına dayalı (Creswell, 2018) amaçlı örnekleme yöntemlerinden biri olan kolay ulaşılabilir örneklem tercih edilmiştir. Bunun yanı sıra, çalışma grubuna katılacak olan kişilerin seçiminde bu çalışmada odaklanılan olguyu, durumu ya da deneyimi yaşamış olan ve yaşadıklarını araştırmacılara derinlemesine aktarabilecek kişilerden seçilmesine özen gösterilmiştir. Veri toplama aşamasında, İstanbul ilinde farklı sektörlerde (muhasebe \& finans, eğitim, bankacılık, sağlık, satış \& pazarlama) faaliyet gösteren örgütlerde (kamu \& özel) görev yapan beyaz yakalı çalışanların kariyerleriyle ilgili yaşamış oldukları endişe deneyimlerini paylaşmaya gönüllü 37 katılımcı ile yarı yapılandırılmış görüşme formları kullanılarak derinlemesine mülakatlar gerçekleştirilmiştir. Çalışma grubunun cinsiyet dağılımına bakıldığında grubun 20 kadın ve 17 erkek çalışandan oluştuğu ve çalışanların yaş ortalamasının 33.2 yıl ve büyük çoğunluğunun lisans mezunu olduğu (27 kişi) görülmektedir, ayrıca 19 çalışanın yöneticilik pozisyonunda görev yaptığı bilinmektedir. Kurum tecrübesi açısından bakıldığında ortalama 6.7 yıldır aynı işyerinde çalıştıkları ve toplam mesleki tecrübelerinin 9.8 y1l olduğu görülmektedir. Katılımcıların aylık kazançlarının ise 2.500TL11.000TL aralığında değiştiği görülmektedir.

\subsection{Veri Geliştirme}

Nitel araştırmalarda aktarılabilirliğin sağlanması için ayrıntılı betimleme yapılması ve örneklemin seçiminde çeşitlilik sağlanması önerilmektedir (Meriam, 2009). Dolayısıyla bu çalışmada, geçerlilik ve güvenilirlik düzeyini arttıran katılımcı çeşitliliğin sağlanması (Miles \& Huberman, 1994) amacıyla kişilerin farklı sektörlerde faaliyet gösteren kurumlarda çalışıyor olmalarına özen gösterilmiştir. Bunun yanı sıra, katılımcılardan yaşamış oldukları kariyer endişesinin nedenleri ile ilgili kişisel deneyimlerini paylaşmaları istenmiş ve böylelikle ayrıntılı betimleme yapma olanağı elde edilmiştir. $\mathrm{Bu}$ doğrultuda, mülakat esnasında öncelikle çalışmanın ilk araştırma sorusuna yanıt aranmıştır (bknz. sayfa. 12). Ayrıca katılımcılara yöneltilen sorular, alanyazın taraması sonrasında oluşturulan kavramsal çerçeve [kariyer endişesi ölçeği (Şahin vd., 2019) ve stres kaynakları (Choi vd., 2011)] doğrultusunda oluşturulmuştur. Aynı zamanda çalışmanın inanılırlığını sağlamak amaciyla (Holloway \& Wheeler, 1996) görüşme soruları örgütsel davranış alanında çalışan üç akademisyen tarafından incelenmiş, soru formunun anlaşılabilirliğini test etmek amacıyla mülakatlar sırasında elde edilen verilerin doğruluğu katılımcılardan onay alınarak denetlenmiş ve görüşme yapılan 10 kişi ile kendi ifadelerine yönelik olarak "katılımcı teyidi" gerçekleştirilmiştir.

\subsection{Veri Analizi}

Araştırmanın veri analizi aşamasında tematik içerik analiz yöntemi temel alınmıştır (Miles \& Huberman, 1994). Bilindiği üzere, içerik analizi bilgi, yeni görüşler, gerçeklerin temsili ve eylemlerin tespit edilmesi noktasında araştırmacılara geniş bilgiler sunabilmektedir (Krippendorff, 2018). Bu bağlamda; katılımcılardan ses kayıt cihazı ve not ile elde edilen ifade kalıpları öncelikle bilgisayar ortamında yazılı hale getirilmiştir. Sonrasında, katılımcıların yaşadıkları kariyer endişesi deneyimleri özünü yansitan önemli ifadelerin içeriklerinden yola çıkarak tümevarımcı analizine uygun olacak şekilde çözümlenmiştir. Tümevarımcı analiz kodlama, katılımcı ifadelerinin altında yatan kavramları ve bu kavramlar arasındaki ilişkileri ortaya çıkarmak amacıyla yapılmaktadır (Yıldırım \& Şimşek, 2013). Kariyer endişesine dair kodlar arasındaki ortak noktalar tespit edilip anlam bütünlüğü sağlanmış ve bu doğrultuda alt-temalar, ortak kodlar arasındaki ilişkileri ele alarak temalar belirlenmiştir. Alt temalara göre yapılan gruplandırma sonrasında ise elde edilen temaların yorumlanma aşamasına geçilmiştir. Nitel veri analizinin son aşamasında ise; araştırmadan toplanan ifade kalıplarına geri dönülmüş ve yapılan kodlamalar kontrol edilmiştir (Miles \& Huberman, 1994). Böylelikle katılımc1 ifadeleri, yapılan kodlamalar, alt-temalar ve temalar yeniden ele alınmış ve ulaşılan sonuçların ifadeleri temsil düzeyi belirlenmiştir. $\mathrm{Bu}$ kontrolün bireysel etkilerden arındırılması amacıyla veri seti alanda 
çalışan üç akademisyene iletilmiş ve aralarındaki görüş birliği oranı belirlenmiştir (\% 86). Bu oranın \%80'in üzerinde çıkmış olması çalışmanın içsel tutarlılığını ve güvenilirliğine katkı sağlaması açısından önemli görülmektedir (Patton, 2002). Bulgular kısmında ayrıca, katılımcıların her bir temayı yansitan ifadelerine yer verilmiştir. Katılımc1lar analiz sürecinde K1，K2，...K37 şeklinde kodlanmıştır.

\section{BULGULAR}

Araştırma sonuçları, çalışanların yaşamış oldukları kariyer endişesinin nedenlerine bağlı olarak aşağıdaki bulguları ortaya koymuștur.

\subsection{Kariyer Endişesine Neden Olan Konular}

Katılımcılar yaşamış oldukları kariyer endişesi deneyimleri doğrultusunda söz konusu endişeyi yaşamalarının altında aşağıda belirtilen nedenlerin olabileceğini vurgulamışlardır. $\mathrm{Bu}$ bağlamda belirlenen tema, alt-tema ve kodlar ile katılımcıların ifadeleri ne kadar sıklıkla kullanıldığına dair bilgiler için Tablo 1'de yer almaktadır.

Kariyer endişesine konu olan temalar sırasıyla; bireysel konular, örgütsel konular, teknolojik konular, toplumsal konular, çalışma arkadaşlarıyla ilgili konular, yönetici ile ilgili konular ve istihdam konuları olarak tespit edilmiştir.

Bireysel konular teması içerisinde, katılımcıların sıklıkla belirttikleri ifade kalıplarında şu alt temalara ulaşılmıştır: kişilerin kazandıkları ücret/gelir ve ekonomik kaynaklarının yetersiz olması, bazı kişilik özellikleri ile iş arasında yetersizlik/korku hissi, çalışma hayatındaki deneyim ve yaş, alınan mesleki eğitim, iş-aile dengesindeki sorunlar, kişinin mesleğe uygunluğu arasındaki belirsizlik ve kariyer yolunda hiçbir değişimin olmayacağına dair inanç gibi psikolojik nedenler bulunmaktadır. Kodlar incelediğinde ise katılımcıların kişisel özelliklerinin kariyerlerine uygun olmadiğı düşüncesi, mesleki bilgi/yetkinlik/yetenek açısından kendini yetersiz görme, başarısız olma/ işsiz kalma korkusu, hak edilenin altında gelir elde edildiği düşüncesi ve tükenmişlik hissi ile ailenin ekonomik ve sosyal ihtiyacından doğan baskının kariyer endişesine neden olan konular olduğunu ifade etmişlerdir. $\mathrm{Bu}$ temaya ilişkin örnek alıntılar şu şekildedir;

'Ilk başta bireyden kaynaklanıyor Kişinin kendisiyle alakall... Kişi-iş uyumu yoksa. İşin gereklilikleri yeterli değilse... Kariyer yolunda kişisel olarak kendini geliştirmiyorsan. $O$ beceri, yetenekte olmuyor olabilirsin ama onu çok istiyor olabilirsin. Bir görevi istiyorsundur ama kendini o göreve kişisel olarak yeterli görmüyorsundur.' (K29, Kadın, Akademisyen)

"Kendimi mesleğimde geliştirmem için öncelikle buna kaynak ayırmam gerekiyor ve ben bu kaynağl yaratacak durumda değilim... Aldı̆̆ım maaş ancak temel ihtiyaçlarımı karşılamaya yetiyor... O nedenle yaşadığım kaygıların temelinde en çok maddi yetersizlikler yatıyor" (K6, Erkek, Avukat)

"Kariyerimle ilgili yaşadığım kaygıların ardında kendime duyduğum güvensizlik yatıyor... Sanki hiçbir zaman başarılı bir iş kadını olmayacağımı ve kariyerimde daha üst noktalara gelemeyeceğimi hissediyorum... Bunun için çaba sarf etmiyorum ve bu durum beni işimden uzaklaştırıyor " (K9, Kadın, Yönetici Asistanı)

Örgütsel konular temasında, üst yönetimindeki nepotisttik yaklaşım, kurum kültürü, kurumun mali, beşeri ve teknolojik kaynaklarının yetersiz kullanımı, insan kaynakları uygulamasına dair alınan kararlar, kurum içindeki örtük iletişim ve üst yönetimin yürüttüğü politikaları yansıtan alttemalar bulunmaktadır. $\mathrm{Bu}$ alt-temaları içeren kodlar incelendiğinde ise; 'performans değerlendirme/işe alım/terfi süreçlerinin liyakat temelli olmaması', rekabet koşullarının çetinleşmesi' 'kurumda yeterli iş pozisyonunun/terfi olanağının bulunmaması', 'mesleki gelişime izin vermeyen kurum kültürü', 'çalışanlar için ayrılan kurum imkânlarının/kaynaklarının yetersizliği’, gibi konulara değinildiği görülmüştür. Bu temaya ilişkin örnek alıntılara aşağıda yer verilmiştir:

'Orada, yönetimde kurulan ilişki var. Ast-üst ilişkisi... Kariyerin karar vericilerin kendilerinde, sirf objektif kriterler değil de çevreleri ile ilişkileri... Bunlar yönlendiriyor, endişe yaratıyor.' (K28, Erkek, Bankacı)

"Çalıştı̆̆ım kurumun yapısı kariyerimde ilerlememe izin verecek bir yapıda değil... Üst pozisyonlarda bir yer açıldığında dışarıdan birini getiriyorlar, bize söylenmiyor... $O$ nedenle bu kurumda ilerleyeceğimi düşünmüyorum ve bu beni geleceğe dönük kaygllandırlyor" (K24, Kadın, Satın Alma Sorumlusu)

\footnotetext{
"Mesleki olarak ilerlememi sağlayacak eğitimler var ve bu ĕgitimleri bizlere çalıştı̆̆ım kurum vermeli... Ama kurumumla konuştuğumda bu eğitimlere ayıracak kaynakları olmadığını kendi çabamızla bu sertifikaları almamı gerektiği söyleniyor" (K8, Kadın, Bilgisayar Mühendisi)
} 
Tablo 1: Kariyer Endişesine Neden Olan Konular

\begin{tabular}{|c|c|c|c|}
\hline TEMA & ALT-TEMA & KODLAR & SIKLIK \\
\hline \multirow{15}{*}{ Bireysel Konular } & \multirow{2}{*}{ Ekonomik Kazanç } & Düşük Maaş & 59 \\
\hline & & Yetersiz Kaynak & 23 \\
\hline & \multirow{4}{*}{ Kişilik Özellikleri } & Öz-yeterlilik Korkusu & 26 \\
\hline & & Özgüven Eksikliği & 24 \\
\hline & & A Tipi Kişilik & 7 \\
\hline & & Başarı İhtiyacı & 6 \\
\hline & \multirow{2}{*}{ İş- Yaşam Dengesi } & Aile baskısı & 21 \\
\hline & & İș-Aile Çatıșması & 5 \\
\hline & \multirow{2}{*}{ Deneyim } & İș Tecrübesi & 22 \\
\hline & & Yas & 3 \\
\hline & Eğitim & Akademik/Mesleki Gelişim & 6 \\
\hline & \multirow{2}{*}{ İş Tatmini } & Kiși-İs Uyumu & 11 \\
\hline & & Farklı is hedefleri & 7 \\
\hline & \multirow{2}{*}{ Psikolojik Nedenler } & Tükenmişlik & 8 \\
\hline & & Öğrenilmiș çaresizlik & 6 \\
\hline \multirow{13}{*}{ Örgütsel Konular } & \multirow{2}{*}{ Nepotizm } & Ahbap-Çavuş Ílişskisi & 20 \\
\hline & & Siyasi Yakınlık & 17 \\
\hline & \multirow{2}{*}{ Örgüt Kültürü } & Örgüt yapısı & 30 \\
\hline & & Kurum Baskısı & 21 \\
\hline & \multirow{3}{*}{ Kaynaklar } & Bütçe & 17 \\
\hline & & Kurumiçi Eğitim & 7 \\
\hline & & Çalıșan Sayısı/Yaşı & 3 \\
\hline & \multirow{3}{*}{$\begin{array}{c}\text { İnsan Kaynakları } \\
\text { Uygulamaları }\end{array}$} & İş Pozisyonu & 11 \\
\hline & & Terfi imkanları & 9 \\
\hline & & Kariyer Engelleri & 6 \\
\hline & Örgütsel İletișim & Gizli Denetim & 11 \\
\hline & Üst Yönetim Politikası & Üst Yönetim kararları & 6 \\
\hline & & Prosedürel Adalet & 3 \\
\hline \multirow{5}{*}{ Teknolojik Konular } & \multirow{2}{*}{ Yetkinlik } & Teknik Beceri & 32 \\
\hline & & Vasıfsızlaşma & 18 \\
\hline & İşgücünün Yapısal & İşi Kaybetme Korkusu & 21 \\
\hline & Değişimi & Makineleşme & 11 \\
\hline & Kurum Adaptasyonu & Güncel Bilgi/Sektör Takibi & 14 \\
\hline \multirow{4}{*}{ Toplumsal Konular } & \multirow{2}{*}{ Sosyo-Kültürel } & Mahalle Baskısı & 23 \\
\hline & & Toplumsal Beklenti & 20 \\
\hline & Değerler/Tutumlar & Pozisyon/Makam/Mevki & 41 \\
\hline & $\begin{array}{l}\text { İş Yaşamında Kadın/ } \\
\text { Toplumsal Cinsiyet Eșitliği }\end{array}$ & Cinsiyetçi Yaklaşım & 11 \\
\hline \multirow{5}{*}{$\begin{array}{c}\text { Calışma } \\
\text { Arkadaşlarıyla } \\
\text { İlgili Konular }\end{array}$} & \multirow{5}{*}{ Çalışma İlişskisi } & Güç Catıșması & 22 \\
\hline & & Rekabet & 21 \\
\hline & & Çıkar Çatışması & 15 \\
\hline & & Kıskançlık & 7 \\
\hline & & Dedikodu & 4 \\
\hline \multirow{5}{*}{$\begin{array}{c}\text { Yönetici ile ilgili } \\
\text { Konular }\end{array}$} & \multirow{3}{*}{ Davranış Biçimi } & Eşit Olmayan Tutum & 17 \\
\hline & & Baskı & 12 \\
\hline & & Ayrımcılık & 10 \\
\hline & \multirow{2}{*}{ Yetkinlik } & Yönetsel Beceri & 20 \\
\hline & & Algilanan Destek & 8 \\
\hline \multirow[t]{2}{*}{ İstihdam Konuları } & $\begin{array}{l}\text { Ülkedeki İstihdam } \\
\text { Koșulları }\end{array}$ & İşsizlik & 27 \\
\hline & Eğitimde Fırsat Eşitliği & Kaynak Erişimi & 12 \\
\hline
\end{tabular}

Teknolojik konular teması içerisinde, teknolojiyi kullanabilme becerisi, yeni teknolojinin yetkinlikleri dönüştürmesi, bilgi çağının beraberinde getirdiği işgücü yapısındaki değişimler, örgütün teknolojik altyapısı ve dijital uygulamaların kişilerde baskı yaratması şeklinde alt-temalar tespit edilmiştir. Kodlar incelediğinde ise katılımcıların hızla gelişen teknolojik programlara ayak uyduramaması, hızlı değişen teknolojinin yeni meslekleri ortaya çıkarmış olması, iş 
tanımlarının/mesleki gerekliliklerin bilgi teknolojisi sonucunda değişmesi, gelişen teknolojilerin kurumlarda işgücü ihtiyacını azaltması kariyer endişesine neden olan konular olarak ifade edilmiştir. Örnek alıntılara aşağıda yer verilmiştir:

'Devlet dairesinde teknoloji çok klsitll. Ayak uyduramamam işin yavaşlamasina ve işten uzaklaşmama sebep oluyor. Teknoloji yetersizliği, ilgisizliği doğuruyor.' (K27, Kadın, Memur)

"Teknolojiyle beraber sosyal medya kullanımı çok arttı... İş arkadaşımın patronumla yemeğe çıktığını sosyal medya hesaplarında görmem beni endişelendiriyor... Insanlar teknolojiyi kullanarak kendilerine bir çevre oluşturuyorlar ve siz kullanmiyorsanı geride kalıyorsunuz" (K20, Kadın, Muhasebe Elemanı)

"Artık robotlar ameliyat yapıyor... Gelecekte bizlere ihtiyaç duyulacak mi bilmiyorum... Bu nedenle kaygl duyuyorum... Bu değişime ayak uyduracak becerilerimizi geliştirebileceğimiz bir altyapı yok” (K27, Erkek, Hekim)

Toplumsal konular temasında, sosyo-kültürel olarak çevrenin kadın ve erkek rolüne yaklaşımı, yine toplumsal çevrenin değer ve inançları alt-tema olarak bulunmuştur. Siklıkla belirtilen kodlar ise; 'çalışan kadına yönelik cinsiyetçi yaklaşımlar', 'toplumsal rollerin kişiler üzerinde aşırı baskı/beklenti oluşturması', 'iş ilişkilerinde nepotizm/kayırma temelli davranışların yoğunluğu' tespit edilmiştir. Bu temaya ilişkin örnek alıntılar şu şekildedir;

"Toplumun gözünde almış olduğunuz eğitimin ve ulaşmak istediğiniz hedeflerin bir önemi yok... Hangi pozisyonda çalıştı̆̆ınız ve kaç TL. maaş aldığınıza bakılıyor... Bu nedenle kariyerime yönelik hedefler oluştururken bunlar benim üstümde baskı yaratıyor" (K17, Erkek, Eğitim Danışmanı)

"Kimsenin ĕgitime ya da kişilerin mutluluğuna önem verdiğini düşünmüyorum... Etrafimdaki herkesin tek düşündüğü kaç TL. maaş aldığım... Kariyer hedefleriymiş, beklentilermiş... Bunlar bizim toplumda üzerinde düşünülen konular değil... Eskiden öğretmenlere saygl duyulurdu şimdi ise klymeti yok” (K18, Kadın, Rehber Öğretmen)

Çalışma arkadaşlarıyla ilgili konular temasında ise çalışma arkadaşıyla iş kaynaklı olan güç çatışması ve rekabet ilişkisi alt-tema olarak tespit edilmiştir. Kodlar incelendiğinde ise 'aşırı rekabetçi/kıskanç/dedikoducu çalışma arkadaşlarının varlığı', 'birliktelikten ziyade bireysel kazançların/egoların ön plana çıktığı güç gösterileri', 'çalışma arkadaşının kişinin başarısının üstüne konması' ifadeleri yer almaktadır. $\mathrm{Bu}$ temaya ilişkin örnek alıntılar;

'Ekip arkadaşımca başarılarımın küçümsenmesi ancak kendi başarılarının abartılması.' (K32, Erkek, Satış Uzmanı)

“Işs arkadaşlarım insanın yüzüne gülüyor ama biliyorum ki arkamdan konuşuyorlar ve beni kiskanıyorlar... Bu nedenle arkamdan neler söylediklerine dair endişe duyuyorum... Belki de yöneticime de olur olmadık seyler söylüyorlar ve bu durum benim kariyerimi etkileyebilir" (K23, Kadın, Laboratuvar Şefi)

"Kurum zor zamanlardan geçerken arkadaşlarımla aramızda bir birliktelik ve paylaşım olmuyor... Herkes kendi gemisinin kaptanı... Yarın bir gün onların desteğine ihtiyaç duyduğumda onlart yanımda göremeyeceğimi biliyorum... Örneğin, haksız yere ișten çıkartılsam arkamda beni savunacak bir arkadaşım bile olmaz" (K25, Kadın, Akademisyen)

Yönetici ile ilgili konular temasında, yöneticinin çalışana davranış biçimi ve yöneticinin yönetsel yetkinlikleri kariyer endişesi yaratan alt-temalar olarak bulunmuştur. Sıklıkla ifade edilen kodlar ise 'baskıc1/psikolojik şiddet uygulayan/adaletsiz yönetici uygulamaları', 'yöneticilerin ayrımc1/cinsiyetçi/adil olmayan söylem ve tutumları', 'yöneticinin çalışanının kariyeri önünde bizzat engel oluşturması', 'yöneticinin çalışanına destek vermemesi' şeklinde belirtilmiştir. Bu konuya ilişkin örnek alıntılar ise;

'Yönetici sebeptir. Kariyer endişesi yaşıyorum. Yönetici karar verici olduğu için... Çalışma tarzı uymaz, o zaman yönetici ĕger seni uygun görmezse kariyerinde seni desteklemez ve kariyerinde doğru ilerleyemezsin. Önüne engel koymast endișesi. Ve yöneticinin yönetememesi.' (K35, Erkek, Bankacl)

"Yöneticimin kadınlara karşı bir önyargısı var... Kadınların yönetici olamayacaklarına dair söylemleri beni endişelendiriyor... Konuşmalarında, evli ve çocuklu kadınların başarılı olamayacağına yönelik mesajlar veriyor... Bu beni çok endişelendiriyor.' (K19, Kadın, Akademisyen)

"Yöneticimin yakın olduğu kişilerle ilişkileri çok farklı ve o grubun içinde olmadığım için bu kurumda kariyerimi ilerletme şansinı bulabileceğimi düşünmüyorum... E Eğer onunla ilişkilerinizi iyi tutarsanız sorun yok ama herhangi bir fikir ayrılı̆̆ına düşerseniz vay halinize (K21, Erkek, Yönetim Danışmanı) 
Son olarak istihdam konuları temasında ülkenin emek piyasaları politikası bağlamında istihdam yapıs1 ve sosyo-ekonomik durumdan ötürü mesleki eğitimdeki fırsat eşitsizliği kariyer endişesine neden olan alt-temalar olarak bulunmuştur. Sıklıkla ifade edilen kodlar arasında 'ülkenin içinde bulunduğu ekonomik kriz/kaynak yetersizliği', 'düşük maaşa razı gelerek çalışmayı kabul etmek', 'ücret düzeyinin kişisel gelişim için yetersiz kalması', 'işsizlik korkusu' olarak tespit edilmiştir. $\mathrm{Bu}$ temaya ilişkin örnek alıntılar şu şekildedir;

'Bir üst kademeye çıkar da başarısız olursam işten atılırım korkusu bu nedenle çalışmaya olan ekonomik ihtiyaç, geçim sıkıntısı.'(K18, Kadın, Bankacl)

"İsssizlik oranları ve ekonomik kriz haberleri endişe duymama neden oluyor... İşimi kaybedeceğime yönelik korkular yaşlyorum... Yaptı̆̆ım işi daha düşük maaşa yapacak bir sürü insan var... Bunları duymak kariyerimle ilgili kayg y yaşamama neden oluyor” (K15, Kadın, Eğitim Danışmanı)

"Çalıştı̆̆ım kurum ekonomik olarak kötü durumda... Belki de iflas edebilir... Bunu düşündükçe korkuyorum ve daha iyi durumda olan bir kuruma geçmek istiyorum ama bunun için de yeni eğitimler almam gerekiyor ve bu ĕgitimler çok pahalı" (K7, Kadın, İ̧ Geliştirme Stratejisti)

\subsection{Kariyer Endişesi ile Mücadele Etmeye Yönelik Yollar}

Araştırmanın ikinci bulgusu olarak katılımcıların yaşadıkları kariyer endişesini paylaşmaları sonucunda bu endişeyle baş etmelerine yönelik yollar ve öneriler dört ana tema şeklinde tespit edilmiştir.

İlk olarak, katılımcıların kariyer dönemlerinde yaşadıkları deneyimlere göre bireysel düzeyde önerilen yollar belirtilmiştir. Bunlar; kişinin kendisini günün şartlarına göre sürekli yenilemesi /kendisine yatırım yapması, umutsuzluğa kapılmamak, yurtdışındaki çalışma imkânlarını araştırmak, üst yönetici ile yüz yüze iletişime geçmek, mesleki pozisyon özelliklerini/gerekliliklerini tam anlamı ile öğrenmek, kendini iyi tanımak/ne istediğini bilmek, stresle mücadele yöntemlerini uygulamak şeklindeki önerileri çoğunlukla ifade ettikleri tespit edilmiştir. Aynı zamanda bazı katılımcılar tarafından yöneticilerinden ve çalışma arkadaşlarından aldığı kariyeri destekleyecek yan/yeni iş kollarına atılma tavsiyesi ya da siyasi bağlantılar bulma yönünde önerilerin de vurgulandığı görülmüştür. Son olarak ise bireysel düzeyde önerilen yollar içerisinde aile ve iş dışındaki çevreden alınan öneriler dahilinde, katılımcıların kariyer kaygısı ile mücadele için kariyer gelişiminde gerekli eğitimin alınması, psikolojik destek alınması ve kendini geliştirme (kurs, sertifika, yüksek lisans vb.) yönündeki ifadeleri tespit edilmiştir.

Örgütsel düzeyde önerilen yollar ise bir diğer mücadele yöntemi olarak katılımcılar tarafından belirtilmiştir. Özellikle çalışma ortamının adil bir yapıya kavuşmasını sağlamak, işe alım ve terfilerde öncelikli olarak iç kaynaklara ağırlık vermek, etkili bir insan kaynakları çalışması ile çalışanların kariyer planlarını yapmak, kadınların terfi mekanizmalarını güçlendirecek kurum içi düzenlemeler yapmak, kurum çalışanlarına bu konuda eğitim vermek, cinsiyete dayalı/ikili/çıkar ilişkilerini ortadan kaldırarak liyakata dayalı yönetim uygulamaları diğer tespit edilen mücadele yöntemleri olmuştur.

Kariyer endişesi ile mücadele yönteminde toplumsal düzeyde önerilen yollar bir diğer tema olarak vurgulanmıştır. Liyakat/adalet duygusunu zedeleyecek gelişmelere toplumsal olarak tepki göstermek, toplumun kariyer kavramına bakış açısını değiştirmesi, kadının çalışmasını destekleyen toplumsal mekanizmaların/yapının oluşturulması katılımcılar tarafından çoğunlukla belirtilen öneriler olmuştur.

Son olarak da bir diğer mücadele yöntemi arasında ekonomik düzeyde önerilen yollar varlığı tespit edilmiştir. Ülkedeki gelir eşitsizliği ve kişilerin ücret eşitsizliğine yönelik politikaların oluşturulması, çalışanlara kariyerlerini geliştirmeye yönelik devlet katkısının/yardımının hayata geçirilmesi katılımcılar tarafından ekonomik düzeyde önerilen yollar olarak ifade edilmiştir.

\subsection{Kariyer Endişesi Sonucunda Kariyer Algısındaki Değişimler}

Katılımcılar tarafından paylaşılan kariyer endişesi sonrasında, günümüzde yaşanan örgütsel ve bireysel değişimlerin kişilerin kariyer algıları üzerindeki etkisi şu şekilde belirtilmiştir:

Katılımcıların önemli bir kısmı kariyer algısının yaşanan değişimlerden etkilendiğini ve bu durumun çalışanlarda; farklı pozisyonlarda /iş yerlerinde iş arayışına girmek; kariyerdeki değişimleri firsat olarak görmek ve hırslanıp daha çok çalışmak; çalışılan şirketin kurumsallaşması yönündeki istekleri arttırmak/üst yönetime bu yönde bask1 yapmak; yurtdışına gitme yönündeki istek \& bu yönde yoğun bir arayışa girmek; daha donanımlı hale gelmek; örgüte yönelik beklentileri değiştirmek; işgücü çeşitliliği; yeni teknolojilere 
uyum sağlayacak şekilde kendini geliştirmek gibi tutum ve davranışları açığa çıkardığı görülmektedir.

Katılımcıların bir kısmı ise, günümüzde yaşanan dönüşümlerin kariyer yolunda herhangi bir değişime neden olmayacağını ifade etmişlerdir. $\mathrm{Bu}$ durumun nedeni ise psikolojik açıdan irdelendiğinde öğrenilmiş çaresizliğin hakim olduğu ve katılımcıların ne yaparlarsa yapsınlar örgüt içinde arzu edilen ilerlemenin kendileri tarafından sağlanamayacağına dair inançlarının olduğu görülmektedir.

\section{SONUÇ VE TARTIŞMA}

$\mathrm{Bu}$ araştırmada, kariyerinin yerleşme (25- 44 yaş) ve sürdürme (45- 64 yaş) döneminde olan çalışanların yaşamış oldukları kariyer endişesine neden olan faktörler ve mücadele yöntemleri tespit edilmeye çalışılmıştır. Araştırmanın çıkış noktası olarak kariyer endişesine yol açabilecek söz konusu etmenlerin neler olabileceği bulgulanmış ve çalışanların kariyer yolculuklarının ilk aşamalarının yanı sıra yerleşme (25- 44 yaş) ve sürdürme (45-64 yaş) dönemlerinde de kariyer endişesinin çalışanlar tarafından belirgin düzeyde hissedildiği tespit edilmiştir. Birinci araştırma sorusu kapsamında 37 katılımcı ile yapılan derinlemesine mülakatların sonuçlarına göre, çalışma ortamında kişilerin kariyer endişesi yaşamalarının altında; bireysel, örgütsel, teknolojik ve toplumsal konuların yanısıra çalışma arkadaşıyla yöneticiyle ve ülkedeki istihdam konularıyla ilgili nedenlerin de olduğu tespit edilmiştir. Bireysel nedenler incelendiğinde; örgütlerin piyasa koşullarına göre verdikleri ücret düzeyi ile ekonomik şartlar, bireyleri yetersiz gelir seviyesi ve artan işsizlik sorunu ile başbaşa bırakmaktadır. Bunun sonucunda kişilerin düşük ekonomik kazançtan dolayı istedikleri yaşam standardını sağlayamamaları kariyer hedeflerini endişeye sevk eden önemli bir unsur olarak belirtilmektedir (Herriot \& Stickland, 1996). Bireysel konular arasından ekonomik kazanç alt teması altında yer alan düşük maaş ise bu çalışmada en sık ifade edilen endişe kaynağıdır (bknz. Tablo 1). $\mathrm{Bu}$ durum motivasyon kuramları ile açıklanabilir. Örneğin, Herzberg'in (1966) Çift Faktör Kuramı bir motivasyon aracı olarak örgütsel dinamiklere açıklık getirmektedir. Hijyen ve motive edici faktörler olarak iki boyuta sahip olan kuramda, hijyen faktörlerinin çalışanı varlığı ile motive etmediği ancak yokluğunun düşük motivasyona sebep olduğu ifade edilmektedir (Alshmemri, Shahwan-Akl \& Maude, 2017). Bu noktada kariyer yolculuğunda bir üst basamağa çıkmak çalışana arzu ettiğinden daha yüksek bir gelir seviyesi sağlamaktadır. Böylece yüksek gelir, artan ücret bağlamında çalışanın motivasyonuna katkıda bulunacaktır. Aynı zamanda, kariyer endişesi duyan bir çalışan için terfi etmek hem maddi açıdan hem de pozisyon açısından elde ettiği ödül ile oldukça kıymetlidir. Uzun kariyer yolculuğunda emek ve gayretleri sonucu adım adım kariyer basamaklarını tırmanan bir çalışan için kariyerinde bir üst basamağa çıkmak hem ekonomik hem de psikolojik açıdan değer taşımaktadır.

Aynı zamanda kariyer endişesine neden olabilecek bir diğer önemli faktörün kişilerdeki bilgi/yetkinlik ve özgüven eksikliği olduğu görülmüştür (Saka vd., 2008). Günümüzde kişilerin, değişen piyasa koşullarına ve iş şartlarına uyum sağlayamayacakları yönündeki inançları, yaşadıkları stresin düzeyini tetiklemekte ve bu durum kişilerde yoğun bir endişe duygusuna neden olabilmektedir (Gümüştekin \& Gültekin, 2009). Bunun yanı sıra, çalışanlar arasında yaşanan rekabetin kişilerin kariyerlerine yönelik güven algılarını (Edmondson, 1999) olumsuz yönde etkilediği ve tükenmişlik içine girmelerine neden olabileceği görülmektedir. Bireylerin psikolojik açıdan örgütlerinde hiçbir değişim olmayacağ algısı ya da gösterdikleri çabaya rağmen herhangi bir ödül ve ilerleme şansı görmemeleri bu araştırmadaki bireysel konular içindeki kariyer endișesini tetikleyen bir diğer ifade olmuştur. $\mathrm{Bu}$ ifadelerin, alanyazında kariyer sorunları içerisinde bireyin kariyerini olumsuz etkileyen bir konu olan kariyer platosu (Dündar, 2010) kavramı ile benzerlik gösterdiği söylenebilir.

Kişilerin yaşadıkları kariyer endişesine, gün geçtikçe artan iş yükü, iş-aile dengesi açısından yaşanan rol belirsizliği ve kurumların kaynak yetersizliği de eklenince, çalışanların geleceklerini bağlı bulundukları kurumlarda görememeleri beklenilen bir sonuç olmaktadır (Sonnentag \& Frese, 2003). Benzer şekilde, bu araştırma sonuçlarından elde edilen bulgulara göre, organizasyon yapıs1, nepotizm ve liyakat sistemine uygun olmayan uygulamalar ile düşük örgütsel adalet algısı çalışanların kariyerleriyle ilgili endişe yaşamalarına neden olabilmektedir. Öyle ki, çalışanların şeffaf olmayan işe alım, terfi/performans değerlendirme sistemlerinden olumsuz yönde etkilendikleri ve benzeri yönetim uygulamalarının kişilerde kariyer endişesine zemin oluşturduğu söylenebilir. Bu noktada çalışanların iş yerinde yaşamış oldukları kariyer endişesini iş stresinin bir parçası olarak ele alındığ 1 görülmektedir (Altaf, 2011; Coetzee \& de Villiers, 2010; Dewa, Thampson \& Jacobs, 2011). Dolayl olarak, Araslı ve Tümer (2008)'in yapmış olduğu çalışma nepotizmin iş stresi üzerindeki etkisini ortaya koymakta ve nepotizm kavramının kariyer endişesinin de önemli bir açıklayıcısı olduğu ifade 
edilmektedir. Diğer bir taraftan Van Hooft ve Stout (2012) çalışmalarında nepotizmin bireylerin kariyerlerinin henüz başındayken karar verme süreçlerinde etkili olduğunu ifade etmişlerdir. Aynı çalışmada bireylerin nepotistik kariyer seçimleri yapma nedenleri de tartışılmış, kayırmacı seçimlerin kariyer memnuniyeti ve ilerleme gibi istihdam sonuçları ile ilişkisi ele alınmıştır. $\mathrm{Bu}$ yönüyle nepotizmin iş arama ve iş seçimi bağlamında önemine dikkat çekilerek bireylerin olas1 kariyer engelinin önüne geçmeyi hedefledikleri iddia edilebilir. Ayrıca bu çalışmada nepotizm algisinin hem ulusal hem de uluslararası alanyazında ele alındığı ve çalışanlar arasında kaygıya neden olduğu da öngörülmektedir.

Kariyer endişesine yol açan konulardan bir diğeri ise günümüz iş dünyasındaki teknolojik dönüşümün (Hirschi, 2018) ve artan makineleşme ile emek sürecindeki dijitalleşmenin kişilerde işsiz kalma korkularını tetiklemesi (Pazzy, 1988) ve vasıfsızlaşma (Akgül \& Önal, 2017) unsuru araştırma kapsamında ortaya çıkan dikkat çekici bir vurgu olmuştur. Öte yandan bu çalışmada, toplumsal konular içerisinde sosyo-kültürel çevrenin etkisi, sosyal ortamın sahip olduğu değer ve inançların kişilerin kariyerinde kaygı unsuru olması bir diğer önemli bulgu olmaktadır. Kariyer ile ilgili yapılan araştırmalarda, çalışanlar kariyer ilerleme sürecinde pek çok sorunla karşılaşmakta ve kariyer sorunlar1/engelleri olarak ifade edilen durum içerisinde bireyin içinde bulunduğu kariyer dönemi, çift kariyerli eşler, cinsiyetten kaynaklanan sorunlar alanyazında en çok ele alınan konular olmuştur (Dündar, 2010). Kadın çalışanların yaşamış oldukları iş-aile/rol çatışmalarını ve karşılaştıkları cinsiyetçi yaklaşımları, kariyerleri açısından önemli bir sorun olarak algıladıkları bilinmektedir (Bliese \& Jex, 2002). Bu nedenle, çalışma grubundaki kadın çalışanların cam-tavan kavramına sıklıkla vurgu yapmalarının, bu olgunun kadın çalışanların endişelerini arttırdığ 1 yönündeki önceki çalışmalarla benzerlik gösterdiği görülmektedir (AkpınarSposito, 2013; Sullivan \& Al Ariss, 2019). Buna ek olarak, katılımcıların beraber çalıştıkları arkadaşlarının tutum ve davranışlarından olumsuz yönde etkilenmeleri bir diğer kariyer endişesi konusu olarak tespit edilmiştir. Katılımcılar, bireysel değerlerin hâkim olduğu rekabetçi örgüt yapılarında kişisel çıkarların giderek önem kazanmasının ve çalışanlar arasında yaşanan güç/statü savaşlarının, kariyerleriyle ilgili endişe yaşamalarına neden olduğunu belirtmişlerdir.

Bununla beraber yöneticilerin çalş̧ana karşı davranış biçiminin ve yönetsel özelliklerinin kişilerin kariyer dönemlerinde kaygı yaşamalarına neden olan bir konu olduğu belirlenmiştir. Araştırma bulguları toksik lider özellikleri taşıyan yöneticilerin, çalışanların kariyer endişesi taşımalarında rolü olabileceğini göstermektedir. Ayrıca, çalışanlar kariyerleri boyunca yöneticilerinin kendilerine engel olacağını düşünmektedirler. Bir diğer ifadeyle, kendilerinin yöneticileri tarafından "rakip" olarak görüldüğünü ifade etmişlerdir. Bu durumun, çalışmanın kariyer endişesiyle ilgili önemli bulgularından biri olduğu düşünülmektedir. Öte yandan, özellikle çok uluslu işletmelerde tepe yöneticileriyle aynı kültürden/düşünceden olmayan çalışanların, bir üst kariyer basamağına geçmeyi hayal dahi edemedikleri görülmüştür.

$\mathrm{Bu}$ çalışmada, ülkede uygulanan istihdam politikalarının kişilerin kariyer dönemlerinde kaygılarını arttıran, özellikle devamlı olarak yükselen işsizlik sorununun ve ücretler arası dengesizliğin önemli bir stres unsuru olduğu diğer çalışmalar tarafından da desteklenen bir konu olmuştur (Dündar, 2010; Watts \& Fretwell, 2004). İstihdam yapısı, bölgeler arası gelir dağılımı, eğitim ve sağlık olanaklarına erişim, işsizlik, nüfus yapısı gibi unsurlar bir ülkenin gelişmişlik düzeyinin göstergeleridir (Çetin \& Sevüktekin, 2016). Ülkenin gelişmişlik derecesi sosyal politika uygulamaları ile paralel olarak kişilerin iş imkanlarını ve kariyerler planlarını etkileyen konulardandır (Watts \& Fretwell, 2004). Bu bağlamda, katılımcıların genel istihdam yapısı ve mesleki gelişim için gerekli olan eğitime erişilebilirlik kapsamında ifade ettikleri kariyer endişesi vurgusu, araştırma sonuçlarının makro düzeydeki istihdam sorunları ve mikro düzeydeki kariyer ilişkisi konusunu desteklediğini göstermektedir.

Ek olarak, ikinci araştırma sorusu doğrultusunda katılımcılar yaşadıkları kariyer endişesinin önüne geçmek amacıyla birtakım bireysel, örgütsel, toplumsal ve ekonomik düzeyde yollar dile getirmişlerdir. Özellikle yetkinlik/öz yeterlilik seviyelerini artırmaya yönelik kişisel gelişim yatırımlarının yapılmasının (bireysel), kurumlarda kariyer planlamalarının yapıldığı insan kaynakları sisteminin oluşturulmasının (örgütsel), toplumdaki kariyer algısının maddi güç/statü algısıyla sınırlandırılmasının önüne geçilmesinin (toplumsal) ve kişilerin gelir düzeylerinin arttırılmasının (ekonomik) katılımcılar tarafindan vurgulanıyor olması, kariyer endişesinin çok yönlü yapısının anlaşılması açısından dikkate değer görülmektedir. Bunun yanı sıra, çalışanların yaşadıkları endişeleri paylaşmaları durumunda çalışma arkadaşlarından ortak/benzer durumları yaşadıklarına dair duygusal destek odaklı öneriler aldıkları tespit edilmiştir. Katılımcılar, aile üyelerinden ve iş dışındaki arkadaşlarından ise daha çok psikolojik/sosyal destek odaklı telkinler ve var olan durumu kabul etmelerine yönelik tavsiyeler aldıklarını ifade 
etmişlerdir. Kişilerin yaşamış oldukları endișeleri yakın gördükleri kişilerle paylaşmaları durumunda somut çözüm önerileri yerine soyut telkinlerin öneriliyor oluşunun, çalışanların yaşamış oldukları endişelerin yoğunluğunun artmasına neden olabileceğine inanılmaktadır.

Çalışanların yerleşme ve sürdürme dönemlerinde yaşamış oldukları kariyer endișesinin altında yatan nedenlerin tespiti ile birlikte örgütsel ve bireysel düzeyde yaşanabilecek birçok olumsuz durumun ortadan kaldırılmasına katkı sağlayacağ 1 düşünülmektedir. Kariyer yolculuğunda bir üst basamağa çıkmak birçok çalışanın arzuladığı ve dolayısıyla motivasyonunu arttırdığ 1 bir durumdur. Hackman ve Oldham (1975) tarafindan sunulan İş Özellikleri Modelinin çıkış noktası, çalışanların iş doyumunu ve motivasyonunu arttırmak için işin zenginleştirmesi ilkesine dayanır. Aynı zamanda modelin içeriğindeki ișe yönelik beș temel özelliğin (beceri çeşitliliği, görev bütünlüğü, görevin önemi, özerklik ve geri bildirim) çalışanın psikolojik durumunu etkilediği ifade edilmektedir (Bilgiç, 2008). Hem örgütsel hem de bireysel açıdan olumlu ve arzu edilen davranışlara rehber olan bu özellikler çalışanın bir gelişme ihtiyacı olarak kariyer döneminde bir üst basamağı hedeflediğini de işaret etmektedir. Bireyin çalışırken gelişen yeteneklerini kullanmasına izin vermek için ise örgütsel ve yönetsel engellerin kaldırılması, çalışanların olumlu psikolojik ruh hali ve örgütsel sağlık açısından işletmelere ipuçları sağlamaktadır. $\mathrm{Bu}$ durumda işletmelerin beşeri sermayesini yöneten insan kaynakları yöneticilerine terfi önünde engel olabilecek örgütsel yapıyı ve yönetsel tutumları tespit ederek kariyer gelişiminin önündeki engelleri kaldırmaları önerilmektedir. Özellikle bu araştırma katılımcılarından 20'sinin kadınlardan oluştuğu düşünüldüğünde, hala kadınların ayrımcılığa maruz kaldıklarını ifade etmeleri günümüz işletmelerinin kadınların iş gücüne olan katkılarına dair algılarını değiştirmeleri gerektiğini göstermektedir.

Yine Tablo 1. 'de örgütsel konular teması altında belirtildiği üzere, örgütsel ve yönetsel konulardan kaynaklanan nedenlerin kültürel etmenler ile etkileşiminin çalışanların kariyer endişesini pekiştirdiği görülmektedir. Bütün boyutları ile örgütsel adaletin (prosedür adaleti, dağıtımsal adalet ve etkileşimsel adalet) hakim olduğu ve kişilerarası eșitliğe dayalı örgütsel prosedür ve ilkelerden oluşan kurum kültürünün çalışanların örgütsel nedenlerden dolayı yaşamış oldukları kariyer endişelerini azaltacağı düşünülmektedir. Ek olarak, insan kaynakları uygulamaları tekrar gözden geçirilerek kariyer basamaklarında eksik olan pozisyonlardan kaynaklı sorunların yöneticiler tarafından yeniden ele alınması önerilmektedir.
Özetle, örgütlerde çalıșanların bilgi, beceri ve deneyimlerini temel alan insan kaynakları uygulamalarının hayata geçirilmesinin, liyakat temelli terfi/ ödüllendirme sistemlerini kuracak bir örgüt kültürünün yaratılmasının ve çalışanların yaşadıkları endişe duygularını paylaşabilecekleri kurum-içi/kurum-dışı destek mekanizmalarının oluşturulmasının gerekli olduğuna inanılmaktadır. Çalışanların özellikle örgütsel ve yönetici ile ilgili konulardan kaynaklı kariyer endişelerini en aza indirmekle hem bireysel hem de örgütsel seviyede pek çok olumlu sonucun doğması beklenmektedir (psikolojik esenlik, iş performansı, iș doyumu, ișe adanma, duygusal ve normatif örgütsel bağlllık, işe katılım, yöneticiye ve örgütsel politika\& prosedürlere güven vb.). Madalyonun öteki yüzü düşünüldüğünde ise örgüt içinde yine yönetici ya da örgütsel konulardan kaynaklı kariyer endişesine yol açan tutum ve davranışlar istenmeyen iş yeri davranışları (örgütsel sinizm, üretkenliğe aykırı çalışma davranışları, işe devamsızlık vb.) ile sonuçlanabilir. Bu tahminler 1şığında, gelecek çalışmalarda kariyer endişesi ile olumlu/olumsuz örgütsel değişkenler arasındaki ilişkilerin incelenmesi önerilmektedir.

Sosyal bilimler alanında yapılan diğer çalışmalarda olduğu gibi bu çalışmada da birtakım kısıtlar bulunmaktadır. İlk olarak bu araştırmaya sadece, İstanbul ilinde faaliyet gösteren örgütlerde çalışan kişilerin katılmış olması araştırmanın en önemli kısıtını oluşturmaktadır. Gelecekte konuyla ilgili yapılacak olan araştırmalarda farklı illerde çalışan kişilere ulaşılmasının ve çalışanların kariyer yolunda karşılaşabilecekleri bireysel (kişilik, rol, yetenek vb.), örgütsel/ yönetsel (örgüt kültürü, liderlik tarzı vb.), toplumsal (sosyo-kültürel yapı vb.), teknolojik ve ekonomik (bilgi teknolojisi, istihdam edilebilirlik vb.) unsurların üzerinde durulmasının, kavramın çok yönlü yapısının daha iyi anlaşılmasına yardımcı olacağı düşünülmektedir. Bunun yanı sıra, literatürde kariyer endişesi kavramının, sadece kişilerin meslek seçimlerinin ilk yıllarında ya da profesyonel hayata ilk başladıkları yıllarda ortaya çıkan bir endişe durumu olarak araştırıldığı göze çarpmaktadır. Ancak, kişilerin kariyerleriyle ilgili yaşadıkları güçlüklerin, karşılaştıkları sorunların ve stres faktörlerinin, hayat boyu devam eden bir süreç olduğu ifade edilmektedir (Creed, Patton \& Prideaux, 2006; Hartung, Porfeli \& Vondracek, 2008; Saka vd., 2008). Bu yönüyle bu çalışmanın, kariyer sürecinde belli bir aşamaya gelmiş kișilerin yaşadıkları endișe kavramına dikkat çeken bir nitel çalışma olması nedeniyle hem kariyer alanyazınına katkıda bulunacağına hem de gelecekteki araştırmacılara yeni bir bakış açısı kazandıracağına inanılmaktadır. 


\section{ETIK BEYANATI}

Destek Bilgisi: Bu çalışma, kamu, ticari veya kâr amacı gütmeyen kuruluşlar gibi herhangi bir organizasyondan destek almamıştır.

Çıkar Çatışması: Tüm yazarlar adına, sorumlu yazar çıkar çatışması olmadığını belirtir.

Etik Onay: İnsan katılımcıları içeren çalışmalarda gerçekleştirilen tüm prosedürler, kurumsal ve / veya ulusal araştırma komitesinin etik standartlarına ve 1964 Helsinki deklarasyonuna ve daha sonraki değişikliklerine veya karşılaştırılabilir etik standartlara uygundur.

Bilgilendirilmiş Onam Formu: Çalışmaya katılan tüm bireysel katılımcılardan bilgilendirilmiş onam formu alınmıștır.

\section{KAYNAKÇA}

Akgül, O. \& Önal, A. (2017). Psiko-sosyal açıdan çalışma ve esneğin rutinleşmesi. ICPESS (International Congress on Politic, Economic And Social Studies), No. 3.

Akpinar- Sposito, C. (2013). Women in management research: theoretical perspective. 4eme FrancoTchèque Trends in International Business. LyonFrance, 11.

Alshmemri, M., Shahwan-Akl, L. \& Maude, P. (2017). Herzberg's two-factor theory. Life Science Journal, 14(5), 12-16.

Altaf, M. (2011). How job stress effect the career satisfaction of an employee? International Conference on Management, Economics And Social Sciences (ICMESS'2011) Bangkok Dec.

Altan, S. (2018). Örgütsel yapıya bağlı stres kaynakları ve örgütsel stresin neden olduğu başlıca sorunlar. Stratejik ve Sosyal Araștırmalar Dergisi, 2(3), 137158

Arasli, H., \& Tumer, M. (2008). Nepotism, favoritism and cronyism: a study of their effects on job stress and job satisfaction in the banking industry of north cyprus. Social Behavior And Personality: An International Journal, 36(9), 1237-1250.

Aytaç, S. (2009). İ̧ stresi yönetimi el kitabı iş stresi: oluşumu, nedenleri, başa çıkma yolları, yönetimi. CASGEM, 1-34.

Aytaç, S. \& Keser, A. (2002). İșsizliğin çalışan birey üzerindeki etkisi: işsizlik kaygısı. The Journal of Industrial Relations And Human Resources, 4(2), 5263.

Bilgiç, R. (2008). İș özellikleri kuramı: Geniş kapsamlı gözden geçirme. Türk Psikoloji Yazıları, 11(22), 6677.

Bliese, P. D. \& Jex, S. M. (2002). Incorporating a mulitilevel perspective into occupational stress research: theoretical, methodological, and practical 1mplications. Journal of Occupational Health Psychology, 7(3), 265.

Brooks, J.L., \& Seers, A. (1991). Predictors of organizational commitment: Variations across career stages. Journal of Vocational Behavior, 38, 53-64.

Choi, B. Y., Park, H. R., Nam, S. K., Lee, J., \& Lee, S. M. (2011). The development and initial psychometric evaluation of the korean career stress inventory for college students. Career Development Quarterly, 59, 559-572.

Coetzee, M., \& De Villiers, M. (2010). Sources of job stress, work engagement and career orientations of 
employees in a south african financial institution. Southern African Business Review, 14(1), 27-57.

Creed, P., Patton, W., \& Prideaux, L. A. (2006). Causal relationship between career indecision and career decision-making self-efficacy: a longitudinal crosslagged analysis. Journal of Career Development, 33(1), 47-65.

Creswell, W. John. (2018) Nitel Araştırma Yöntemleri; Beş Yaklaşıma Göre Nitel Araştırma ve Araştırma Deseni. Bütün, M. \& Demir, S. (Çev.). Siyasal Kitabevi.

Çetin, I. \& Sevüktekin, M. (2016). Türkiye'de Gelişmişlik Düzeyi Farklılıklarının Analizi. Uluslararası Ekonomik Araştırmalar Dergisi, 2(2), 39-61.

Dewa, C. S. Thompson, A. H. \& Jacobs, P. (2011). Relationships between job stress and worker perceived responsibilities and job characteristics. The IJOEM, 2(1 January).

Dündar, G. (2010). Kariyer geliştirme. Uyargil, C., Adal, Z., Atay, İ.D., Acar, A.C., Özçelik, O., Sadullah, Ö., Dündar, G., Tüzüner, V.L. (Ed.). İnsan kaynakları yönetimi. 5. Baskı, Beta Basım Yayım Dağıtım. İstanbul.

Edmondson, A. (1999). Psychological safety and learning behavior in work teams. Administrative Science Quarterly, 44(2), 350-383.

Fiori, M., Bollmann, G. \& Rossier, J. (2015). Exploring the path through which career adaptability increases job satisfaction and lowers job stress: the role of affect. Journal of Vocational Behavior, 91, 113-121.

Gordon, A. T. (1994). Organizational stress and stress management programs. International Journal of Stress Management, 1(4), 309-322.

Gümüştekin, G. E. \& Gültekin, F. (2009). Stres kaynaklarının kariyer yönetimine etkileri. Dumlupınar Üniversitesi Sosyal Bilimler Dergisi, 23(2), 147-158.

Hackman, J. R., \& Oldham, G. R. (1975). Development of the job diagnostic survey. Journal of Applied psychology, 60(2), 159.

Hardin, E. E., Varghese, F. P., Tran, U. V. \& Carlson, A. Z. (2006). Anxiety and career exploration: gender differences in the role of self-construal. Journal of Vocational Behavior, 69(2), 346-358.

Hartung, P. J., Porfeli, E. J. \& Vondracek, F. W. (2008). Career adaptability in childhood. The Career Development Quarterly, 57(1), 63-74.

Herriot, P. \& Stickland, R. (1996) Career management: the issue of the millennium. European Journal of Work And Organizational Psychology, 5:4, 465-470.
Hirschi, A. (2018). The fourth industrial revolution: 1ssues and 1mplications for career research and practice. The Career Development Quarterly. 66(3), 192-204.

Holloway, I., \& Wheeler, S. (1996). Qualitative research for nurses. Oxford: Blackwell Science Ltd.

Johns, G., \& Saks, A. M. (2001). Organizational behaviour: Understanding and managing life at work. Toronto: Addison Wesley Longman.

Köktürk, M. \& Yalçın, A. (2000). Kariyer planlamasında işletme eğitiminin rolü ve bir uygulama. 8. Ulusal Yönetim Ve Organizasyon Kongresi Bildiriler Kitabı. Erciyes Üniversitesi-Nevşehir, 753-768.

Krippendorff, K. (2018). Content Analysis: an introduction to its methodology. Sage Publications.

Meriam, S. B. (2009). Oualitative research: a guide to desing and implementation. San Francisco, CA: Jossey-Bass

Miles, M. B. \& Huberman, A. M. (1994). Qualitative data analysis: an expanded sourcebook. Thousand Oaks, CA: Sage.

Patton, M. Q. (2002). Qualitative research \& evaluation methods. 3rd edition. Sage Publications, Inc.

Pazzy, A. (1988). Joint responsibility: the relationships between organizational and individual career management and the effectiveness of careers. Group \& Organization Studies. 13(3), 311-331.

Pisarik, C. T., Rowell, P. C., \& Thompson, L. K. (2017). A phenomenological study of career anxiety among college students. The Career Development Quarterly, 65(4), 339-352.

Saka, N., Gati, I., \& Kelly, K. R. (2008). Emotional and personality-related aspects of career-decision-making difficulties. Journal of Career Assessment, 16(4), 403-424.

Savickas, M. L. (2001). A developmental perspective on vocational behaviour: career patterns, salience, and themes. International Journal for Educational and Vocational Guidance, 1(1-2), 49-57.

Savickas, M. L., Nota, L., Rossier, J., Dauwalder, J. P., Duarte, M. E., Guichard, J. \& Van Vianen, A. E. (2009). Life designing: a paradigm for career construction in the 21st century. Journal of Vocational Behavior, 75(3), 239-250.

Schein, E. H. (1983). Individuals and careers. Alfred P. Sloan School of Management. Cambridge Ma.

Sonnentag, S., \& Frese, M. (2003). Stress in organizations. Handbook of Psychology, 453-491.

Sullivan, S. E., \& Al Ariss, A. (2019). Making sense of different perspectives on career transitions: a review 
and agenda for future research. Human Resource Management Review, 100: 727.

Sullivan, S. E., \& Arthur, M. B. (2006). The evolution of the boundaryless career concept: Examining physical and psychological mobility. Journal of Vocational Behavior, 69, 19-29.

Super, D. E. (1990). A Life-Span, Life-Space approach to career development. Brown D. \& Brooks L. (Ed.), Career Choice and Development. 2nd Edition: 197261. San Francisco: Jossey-Bass.

Şahin, S., Özaydın, S., \& Siyez, D. M. (2019). Yetişkin Kariyer Endişeleri Ölçeği Kısa Formu: Türkçeye Uyarlama, Geçerlik ve Güvenilirlik Çalışması. Kariyer Psikolojik Danışmanlığı Dergisi, 2(2), 166193.

Tsai, C. T. S., Hsu, H., \& Yang, C. C. (2017). Career decision self-efficacy plays a crucial role in hospitality undergraduates' Internship efficacy and career preparation. Journal of Hospitality, Leisure, Sport \& Tourism Education, 21, 61-68.

Van Hooft, E. A. J. \& Stout, T. (2012). Nepotism and career choice, job search, and job choice. Jones R. G. (Ed.), Nepotism in Organizations (p. 67-91). Routledge/Taylor \& Francis Group.

Wang, M., \& Wanberg, C. R. (2017). 100 years of applied psychology research on individual careers: From career management to retirement. Journal of Applied Psychology, 102(3), 546-563.

Watts, A. G. \& Fretwell, D. H. (2004). Public policies for career development; Case studies and emerging issues for designing career information and guidance systems in developing and transition economies. World Bank Education Advisory Service.

White, N. J. \& Tracey, T. J. (2011). An examination of career indecision and application to dispositional authenticity. Journal of Vocational Behavior, 78(2), 219-224.

Wood, G. J. (2006). Career advancement in Australian middle managers: a follow-up study. Women in Management Review. 21(4), 277-293.

Yıldırım, A. \& Şimşek, H. (2013). Sosyal Bilimlerde Nitel Araştırma Yöntemleri. Ankara: Seçkin Yayıncılık. 